Jpn. J. Oral Biol., $39:$ 297-303, 1997.

\title{
ORIGINAL
}

\section{Formation of adrenochrome from epinephrine by myeloperoxidase via a free radical : Its biological significance}

\author{
Takeshi Odajima and Mihoko Onishi \\ Department of Oral Biochemistry, School of Dentistry, Health Sciences University \\ of Hokkaido, Tobetsu, Hokkaido 061-02, Japan \\ (Received on January 31, 1997 : Accepted on May 19, 1997)
}

Key words : myeloperoxidase/adrenochrome/epinephrine/free radical/electron-spin-resonance

\begin{abstract}
Adrenochrome, 2, 3-dihydro-3-hydroxy-1-methyl-1H-indole-5, 6-dione, is an unstable red compound formed by the oxidation of epinephrine, (R) -4-[1-hydroxy-2-(methylamino) ethyl] -1, 2-benzenediol. A red pigment was generated during the reaction between epinephrine and hydrogen peroxide by myeloperoxidase via a short-lived intermediate having a free radical detected by electron paramagnetic (spin) resonance spectroscopy, possibly o-semiquinone free radical of the substrate (epinephrine), in a moderately alkaline $\mathrm{pH}$ buffer solution. The light absorption peaks of the pigment at 220,302 and $485 \mathrm{~nm}$ were identical with those of adrenochrome, and the Rf-value of the pigment on thin layer chromatography was consistent with that of standard adrenochrome. From these findings, the pigment was concluded to be adrenochrome. The biological significance of the formation of adrenochrome by the myeloperoxidase system in vivo might relate to a possible role in the body's self-defense system : myeloperoxidase released from neutrophils may catalyze the conversion of epinephrine to adrenochrome at a site of trauma or phlogosis, and this adrenochrome would promote wound healing through the formation of a blood clot and/or scab by radical polymerization of body-fluid components around the affected part, resulting in acceleration of hemostasis.
\end{abstract}

抄録：ミエロペルオキシダーゼの触媒作用によって，弱アルカリ性の溶液中で，エピネフリン， $(\mathrm{R})-4-[1-$ hydroxy-2-(methylamino) ethyl] -1，2-benzenediol, からアドレノクローム, 2, 3-dihydro-3-hydroxy-1methyl-1H-indole-5, 6-dione, が生成されることを吸収スペクトルの測定と薄層クロマトグラフィーを用いて証 明した。このアドレノクロームの生成反応はエピネフリンのo-セミキノンと考えられるフリーラジカルをもつ短 寿命の中間体を経由して進行していることが電子スピン共鳴（ESR）スペクトルの観測から証明された。このミ エロペルオキシダーゼによって生成されるアドレノクロームの生体内の役割として, 創傷, 炎症の場において, ラジカル重合によって止血し, 泇皮形成を促し, 病巣を速やかに治瘾させることによって, 生体を防御している 可能性が考えられた。

\section{Introduction}

Adrenochrome is a well-known antihemorrhagic substance that is used clinically. It is formed from epinephrine ${ }^{1,2)}$, a sympathomimetic hormone produced by the adrenal medulla as $\mathrm{L}$-form in animals and man, as reviewed by Loewe $^{3 \text { ) }}$, in a reaction at $\mathrm{pH} 5.0$ catalyzed by catechol oxidase (EC 1. 10. 3. 1) from the mushroom Agaricus campestris. It has been reported that at high $\mathrm{pH}$, adrenochrome was formed from the oxidation of epinephrine by ceric, permanganate or ferricyanide $^{4)}$ or during the autooxidation of epinephrine ${ }^{5}$. We previously reported that myeloperoxidase catalyzes the reaction between epinephrine and hydrogen peroxide in neutral $\mathrm{pH}$ buffer solution to form a pigment having a light absorption peak at $485 \mathrm{~nm}$, which was tentatively identified as 
adrenochrome $^{6)}$. Myeloperoxidase (EC 1.11.1.7) is a unique peroxidase, which has a heme similar to heme $a$ as the prosthetic group ${ }^{7,8)}$ and catalyzes peroxidation of phenolic hydrogen donors such as $o$-methoxyphenol in neutral or alkaline solution ${ }^{7}$. It also catalyzes peroxidation of halides ${ }^{9}$, chlorination of prostaglandin $\mathrm{E}_{1}{ }^{10)}$, destruction of chemical compounds such as fuchsin basic and acid red No. $106^{11}$, and cytolysis of B-16 melanoma tumor cells ${ }^{12)}$ in the presence of a halide ion in moderately acidic conditions. It has been reported that free radicals were formed during the oxidation of epinephrine by inorganic redox agents ${ }^{4}$. It has also been reported that a semiquinone free radical was observed when hydroquinone as hydrogen donor was peroxidized by horseradish peroxidase, by using a flow method coupled with electron paramagnetic resonance spectroscopy ${ }^{13)}$.

The aims of the present study were (a) to determine whether a semiquinone free radical of the substrate, epinephrine, is formed as an intermediate during the reaction between epinephrine and hydrogen peroxide catalyzed by myeloperoxidase, (b) to determine whether the light absorption peaks and Rf-value of the product of this reaction coincide in positions with those of standard adrenochrome, i. e., to confirm the identification of the pigment as adrenochrome, (c) to determine the $\mathrm{pH}$-optimum of this reaction, and (d) to discuss the biological significance of the adrenochrome formed by this peroxidase system in terms of trauma and phlogosis.

\section{Materials and Methods}

Myeloperoxidase was prepared from polymorphonuclear leukocytes of normal pig blood ${ }^{8}$. The concentration of myeloperoxidase was calculated on the basis of a millimolar extinction coefficient of 95 $\mathrm{mM}^{-1} \mathrm{~cm}^{-1}$ at $430 \mathrm{~nm}$. The myeloperoxidase preparation typically exhibited R. $Z$. value $\left(\mathrm{A}_{430 \mathrm{~nm}} / \mathrm{A}_{280 \mathrm{~nm}}\right)$ of 0.85 and was previously confirmed to produce a single band on polyacrylamide gel electrophoresis. Adrenochrome and epinephrine (L-adrenalin) were purchased respectively from Sigma Co. (St. Louis) and Wako Chemical Industries (Osaka). Epinephrine and adrenochrome in the present study were dissolved in
$0.1 \mathrm{M}$ acetic acid and water respectively. The concentration of epinephrine was estimated from the molar extinction coefficient of 2,754 at $280 \mathrm{~nm}$ in $0.1 \mathrm{M}$ $\mathrm{HCl}^{14}$. The concentration of adrenochrome was estimated from the molar extinction coefficient of 3,981 at $490 \mathrm{~nm}$ in water ${ }^{14}$. Spectrophotometry was carried out by Hitachi double beam spectrophotometer, type 200-20, or Hitachi double wavelength-double beam spectrophotometer, type 557. Thin layer chromatography was carried out using a Merck silica gel TLC plate (type RP-8 $F_{2545}$ ). Samples for the thin layer chromatography were prepared as follows. Hydrogen peroxide $(0.4 \mathrm{mM})$ and myeloperoxidase $(16 \mathrm{nM})$ were added to $7.5 \mathrm{mM}$ epinephrine solution in $0.08 \mathrm{M}$ acetic acid mixed with $0.1 \mathrm{M}$ potassium phosphate (dibasic) solution ( $\mathrm{pH} \mathrm{6.0)}$ and this reaction mixture was incubated for $20 \mathrm{~min}$. Immediately, an aliquot of $10 \mu l$ of the reaction mixture was applied. The colored spot was ascertained visually. Detection of the spots was also carried out under ultraviolet light at wavelength $254 \mathrm{~nm}$. The electron paramagnetic (spin) resonance spectrometer used was a Varian V-4500 x-band instrument, utilizing a 100 kcycles field modulation attached flow apparatus, equipped with dual sample chambers $^{15)}$. One chamber was filled with $1 \mathrm{mM}$ epinephrine and $0.2 \mathrm{mM}$ hydrogen peroxide in $0.1 \mathrm{M}$ phosphate buffer ( $\mathrm{pH} 7.0$ ), and the other with $0.7 \mu \mathrm{M}$ myeloperoxidase in the same buffer. The flow rate of the mixture was $8 \mathrm{~m} l$ per second. The control experiments were carried out using water instead of myeloperoxidase or hydrogen peroxide, or by stopping the flow.

The buffers used were acetate (acetic acid/sodium acetate) for $\mathrm{pH}$ 4.0-6.0, phosphate (potassium phosphate, monobasic/sodium phosphate, dibasic) for $6.0^{-}$ 8.0 and borate (boric acid/sodium carbonate) for $\mathrm{pH}$ 8.0-9.0.

All experiments were carried out at $25^{\circ} \mathrm{C}$.

\section{Results}

A pigment with light absorption peaks at 220, 302 and $485 \mathrm{~nm}$, clearly consistent with those of adrenochrome, was formed from the reaction between epinephrine, which does not absorb in the visible region, 
and hydrogen peroxide catalyzed by myeloperoxidase (Fig. 1). As shown in the inset of Figure 1, the formation of this pigment was observed in the presence of myeloperoxidase, but no reaction was observed when myeloperoxidase was omitted. This reaction was accelerated by increasing the concentration of myeloperoxidase, hydrogen peroxide or epinephrine (Figs. 2, 3 and 4). The rate constant, $k_{4}$, for the reaction between myeloperoxidase hydrogen peroxide complex (compound II) and epinephrine was calculated to be $8.8 \times 10^{4} \mathrm{M}^{-1} \mathrm{sec}^{-1}$ from the result of Figure 4 by Chance's equation ${ }^{16)}$ for overall kinetics. The effect of $\mathrm{pH}$ on the peroxidation of epinephrine mediated by myeloperoxidase was examined in the range of $\mathrm{pH} 4.0$ to 9.0 (Fig. 5). The fastest rate was

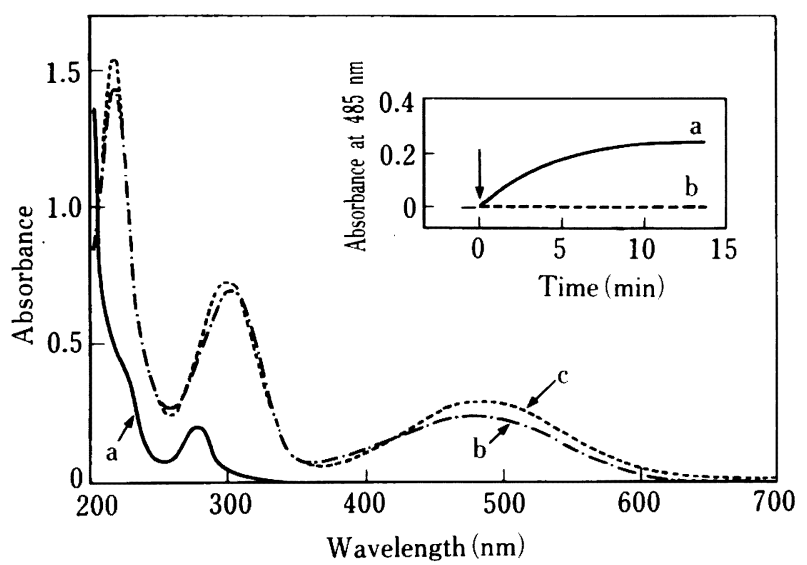

Fig. 1 Light absorption spectra of pigment formed by the reaction between epinephrine and hydrogen peroxide catalyzed by myeloperoxidase and the standards, epinephrine and adrenochrome.

Curve a shows the light absorption spectrum of epinephrine $(73 \mu \mathrm{M})$ in $0.05 \mathrm{M}$ phosphate buffer ( $\mathrm{pH} 7.5)$. Curve $\mathrm{b}$ shows the light absorption spectrum recorded 15 min after hydrogen peroxide $(40 \mu \mathrm{M})$ and myeloperoxidase $(16 \mathrm{nM})$ were added to epinephrine $(73 \mu \mathrm{M})$ in 0.05 $\mathrm{M}$ phosphate buffer ( $\mathrm{pH}$ 7.5). Curve $\mathrm{c}$ shows the light absorption spectrum of $68 \mu \mathrm{M}$ adrenochrome in $0.05 \mathrm{M}$ phosphate buffer $(\mathrm{pH} 7.5)$.

Inset shows the changes in absorbance at $485 \mathrm{~nm}$ with time for the reaction mixture in the presence (time course a) or absence (time course b) of myeloperoxidase. The conditions were the same as curve (b). The reaction was started by adding myeloperoxidase (time course a) or hydrogen peroxide (time course b) at the time shown with an arrow. observed at $\mathrm{pH} 8.0$ in phosphate buffer. To identify the pigment formed from epinephrine by the myeloperoxidase system, thin layer chromatography was performed. When the reaction mixture of epinephrine, hydrogen peroxide and myeloperoxidase was spotted to chromatoplate, air dried and developed, only one pink spot was observed (Fig. 6A). The Rf-value of the pink component was 0.74 , which was clearly consistent with that of the pink spot ${ }^{17)}$ of standard adrenochrome. Both were short-lived and darkened within approximately $20 \mathrm{~min}$. Under ultraviolet light of $254 \mathrm{~nm}$, two fluoresced spots were detected and their Rf-values, 0.92 and 0.74 were within the standards of epinephrine (Rf, 0.92) and adrenochrome (Rf, 0.74), respectively (Fig. 6B). When myeloperoxidase was omitted from the reaction mixture, no spot equal to adrenochrome was detected visibly or under UV. From these findings, it was concluded that the pigment having absorption peaks at 220,302 and $485 \mathrm{~nm}$ was adrenochrome. During the reaction, in which adrenochrome was formed from epinephrine catalyzed by myeloperoxidase, a shortlived intermediate with a free radical, possibly a semiquinone free radical of epinephrine, was detected by electron paramagnetic (spin) resonance spectroscopy (Fig. 7A). Small signals observed in the spectra

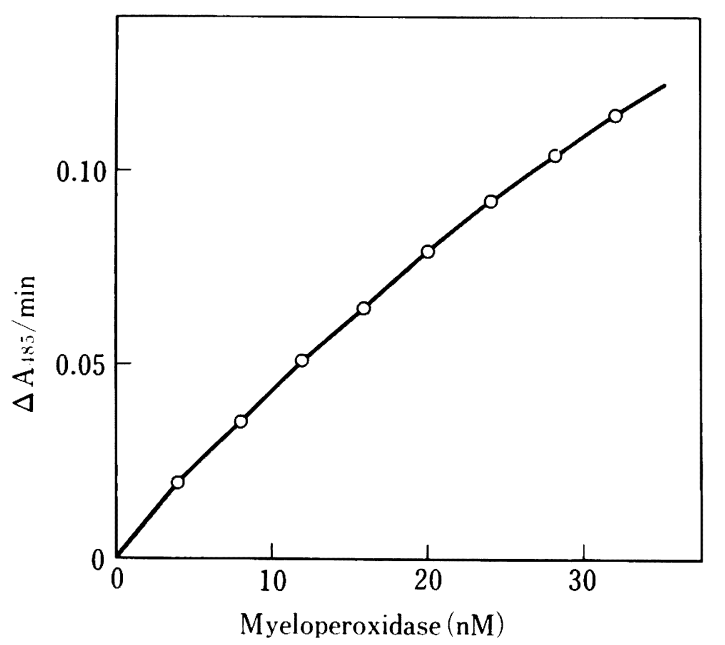

Fig. 2 Effect of myeloperoxidase concentration on the formation of adrenochrome.

The activity was assayed at $0.33 \mathrm{mM}$ epinephrine, $40 \mu \mathrm{M}$ hydrogen peroxide and $0.05 \mathrm{M}$ phosphate buffer ( $\mathrm{pH} 7.5$ ) and at variable concentrations of myeloperoxidase. 


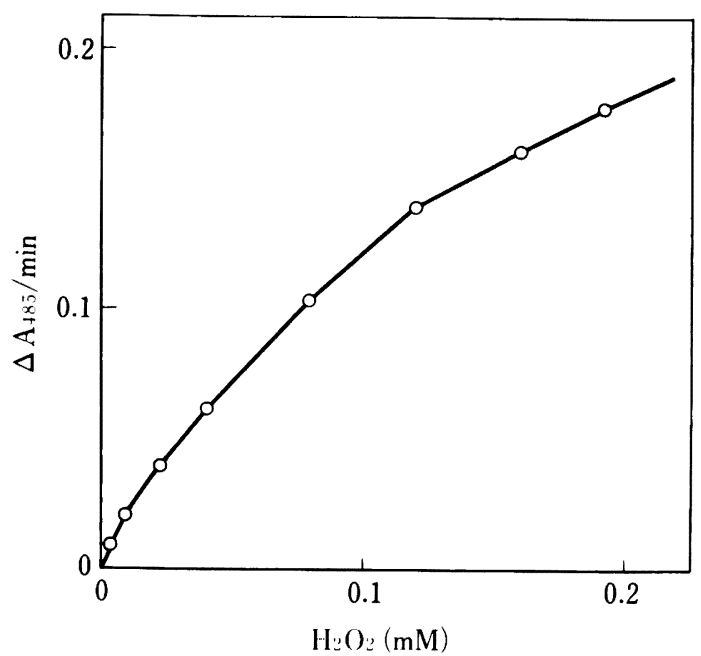

Fig. 3 Effect of hydrogen peroxide concentration on the formation of adrenochrome.

The activity was assayed at $0.33 \mathrm{mM}$ epinephrine and 16 $\mathrm{nM}$ myeloperoxidase and $0.05 \mathrm{M}$ phosphate buffer $(\mathrm{pH} 7.5)$ and at variable concentrations of hydrogen peroxide.

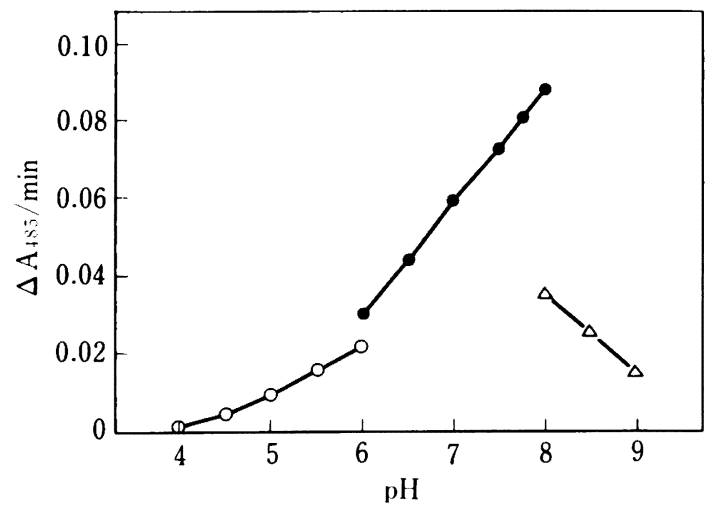

Fig. 5 Effect of $\mathrm{pH}$ on the formation of adrenochrome.

Reaction mixture contained $0.33 \mathrm{mM}$ epinephrine, $40 \mu \mathrm{M}$ hydrogen peroxide and $16 \mathrm{nM}$ myeloperoxidase. The buffers used were acetate for $\mathrm{pH}$ 4.0-6.0 (-O-O-), phosphate for 6.0-8.0 (-- - - ) and borate for $\mathrm{pH} 8.0^{-}$ $9.0(-\triangle-\triangle-)$ at concentrations of $0.05 \mathrm{M}$.

of control samples without myeloperoxidase or hydrogen peroxide were negligible in comparison with the intensity of signals in the complete system composed of epinephrine, hydrogen peroxide and myeloperoxidase (Fig. 7, curves $\mathrm{C}$ and $\mathrm{E}$ ).

\section{Discussion}

The pigment formed by the peroxidation of epi-

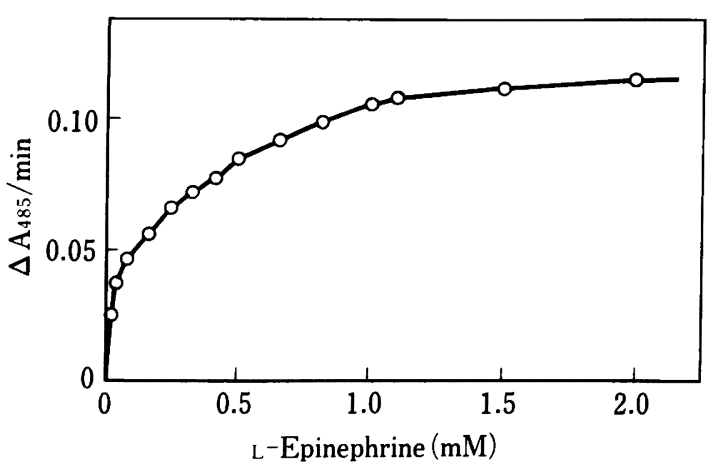

Fig. 4 Effect of epinephrine concentration on the formation of adrenochrome.

The activity was assayed at $40 \mu \mathrm{M}$ hydrogen peroxide and $16 \mathrm{nM}$ myeloperoxidase and $0.05 \mathrm{M}$ phosphate buffer $(\mathrm{pH} 7.5)$ and at variable concentrations of epinephrine.
(A)

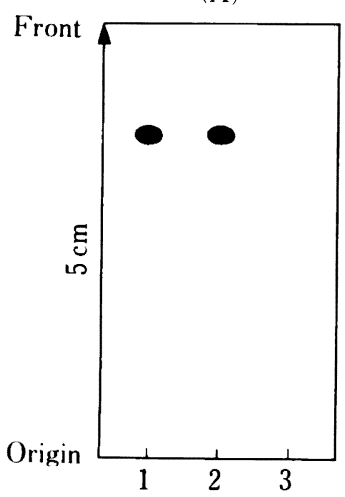

(B)

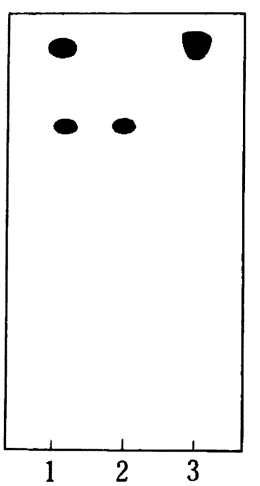

Fig. 6 Thin layer chromatograms of the product formed by the reaction of epinephrine, hydrogen peroxide and myeloperoxidase, and the standards, epinephrine and adrenochrome.

1. Reaction mixture. The reaction mixture contained $7.5 \mathrm{mM}$ epinephrine, $0.4 \mathrm{mM}$ hydrogen peroxide and $16 \mathrm{nM}$ myeloperoxidase $(\mathrm{pH} \mathrm{6.0)} ; 2$. standard adrenochrome $; 3$. standard epinephrine. A : Self-indicating (a pink color) ; B : fluorescing when exposed to ultraviolet light of wavelength $254 \mathrm{~nm}$. The developing solvent was a mixture of methanol and $0.1 \mathrm{M}$ acetate buffer $(\mathrm{pH} 4.5)(9: 1, \mathrm{v} / \mathrm{v})$. Other conditions are detailed in Materials and Methods.

nephrine mediated by myeloperoxidase at neutral $\mathrm{pH}$ was identified as adrenochrome by measuring its absorption spectrum and Rf-value by thin layer chromatography and comparing it with those of standard adrenochrome (Figs. 1 and 6). The adrenochrome formation rate increased with the increased concentration of myeloperoxidase, hydrogen peroxide 


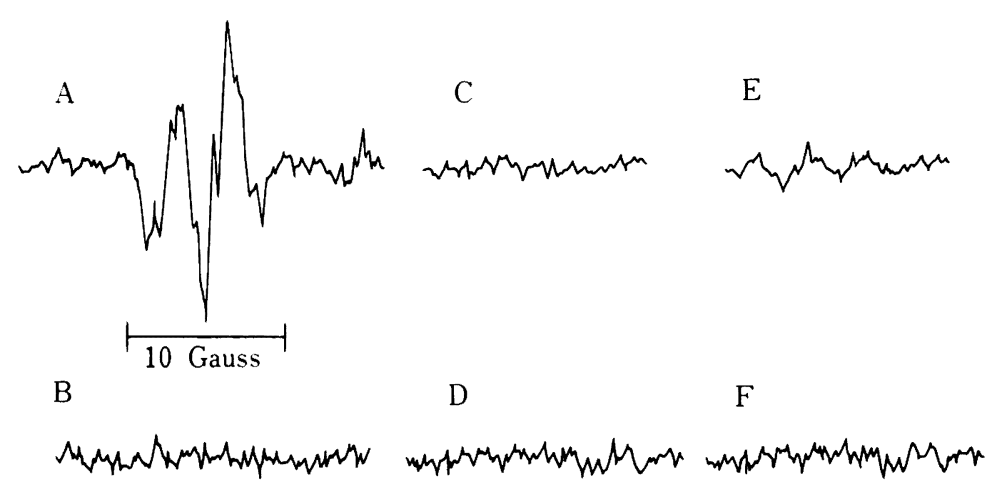

Fig. 7 Electron paramagnetic (spin) resonance spectrum of semiquinone free radical observed during the reaction between epinephrine and hydrogen peroxide mediated by myeloperoxidase.

A : Semiquinone free radical. B : Control, traced by stopping the flow under the conditions of (A). C : Control, traced under flowing (water was used instead of myeloperoxidase). D : Control, traced by stopping the flow under the conditions of (C). E: Control, traced under flowing (water was used instead of hydrogen peroxide). F : Control, traced by stopping the flow under the conditions of (E). The reaction conditions are detailed in Materials and Methods.

or epinephrine (Figs. 2, 3 and 4). The value of a rate constant, $k_{4}$, which is a parameter to show the magnitude of peroxidase activity of myeloperoxidase toward epinephrine, was comparable with that of the $k_{4}$ of this enzyme toward $o$-methoxyphenol ${ }^{7}$. From this, it was concluded that the conversion of epinephrine to adrenochrome mediated by myeloperoxidase was due to the peroxidase activity of this enzyme. We also detected free radicals, possibly the $o$-semiquinone free radical of epinephrine, generated from epinephrine by myeloperoxidase. Adrenochrome may be generated by the following reactions:

2 Epinephrine $+\mathrm{H}_{2} \mathrm{O}_{2} \stackrel{\text { Myeloperoxidase }}{\longrightarrow} 2 \quad$ o-Semiquinone free radical $\stackrel{\text { Dismutation }}{\longrightarrow}$ Adrenochrome + Epinephrine.

This mechanism is basically the same as that of the peroxidation of hydroquinone catalyzed by horseradish peroxidase reported by Yamazaki et al. ${ }^{13)}$. However the myeloperoxidase also catalyzes the peroxidation of halides, chloride, bromide and iodide at low acidity ${ }^{9}$. Furthermore, as reported in previous papers $^{10 \sim 12)}$, at moderately acidic $\mathrm{pH}$, the optimum $\mathrm{pH}$ values being between 4.7 and 5.5 , this peroxidase together with hydrogen peroxide and a halide constitutes a potent oxidation system, which destroys targets such as fuchsin basic and acid red No. 106, halogenates prostaglandin $E_{1}$ and cytolyzes melanoma cells, resulting in the death of the cells. This range of $\mathrm{pH}$ change, from neutral or slightly acidic to moderately acidic ( $\mathrm{pH} 4.7$ to 5.2 ), occurs in the cytoplasm of leukocytes during phagocytosis as reported by Pavlov and Solov'ev ${ }^{18}$, suggesting that the action of myeloperoxidase in neutrophils at acidic $\mathrm{pH}$ is dependent on a halide ion.

The present study suggests a further biological role of myeloperoxidase in the promotion of healing. At a site of trauma or phlogosis, where there is an accumulation of body fluids, which normally lie within the range from neutral to slightly or moderately alkaline, or where the environment becomes neutral to slightly alkaline, the myeloperoxidase released from neutrophils ${ }^{19.20)}$ functions as part of a system generating adrenochrome. This, in turn, may participate in wound healing by promoting the formation of a blood 
clot and/or scab by radical polymerization, forming a melanin-like substance ${ }^{11}$, and resulting in the acceleration of hemostasis ${ }^{2,21,22)}$.

In conclusion, myeloperoxidase may act in two ways in the body's self-defense system. One is in a halide-dependent reaction system scavenging xenobiotics directly in moderately acidic conditions in lysosomes acidified on stimulation by xenogenous substances. The other is in the adrenochrome-generating system in moderately alkaline conditions in resting lysosomes of neutrophils, outside of the lysosomes in neutrophils, or outside of the cells. Thus, it appears that the biological function of myeloperoxidase is regulated by the change of $\mathrm{pH}$ in the environment.

\section{References}

1) Green, D. E. and Richter, D. : LXXXIII. Adrenaline and adrenochrome. Biochem. J. 31 : 596 616, 1937.

2) Heacock, R. A. : The chemistry of adrenochrome and related compounds. Chem. Rev. 59:181 237, 1959.

3) Loewe, H.: Zum fünfzigjährigen Jubiläum der ersten Hormon-Synthese. Suprarenin und seine Derivate. Arzneimittel-Forsch. $4: 583 \sim 598,1954$.

4) Borg, D. C. : Transient free radical forms of hormones:EPR spectra from catecholamines and adrenochrome. Proc. Natl. Acad. Sci. U. S. A. 53: 633 639, 1965.

5) Misra, H. P. and Fridovich, I. : The role of superoxide anion in the autoxidation of epinephrine and a simple assay for superoxide dismutase. J. Biol. Chem. $247: 3170 \sim 3175,1972$.

6) Odajima, T.: Myeloperoxidase of the leukocyte of normal blood. II. The oxidation-reduction reaction mechanism of the myeloperoxidase system. Biochim. Biophys. Acta $235: 52 \sim 60,1971$.

7) Odajima, T. and Yamazaki, I. : Myeloperoxidase of the leukocyte of normal blood. V. The spectral conversion of myeloperoxidase to a cytochrome oxidase like derivative. Biochim. Biophys. Acta $284: 368 \sim 374,1972$.

8) Odajima, T. : Myeloperoxidase of the leukocyte of normal blood. Nature of the prosthetic group of myeloperoxidase. J. Biochem. $87: 379 \sim 391,1980$.

9) Onishi, M., Nakamura, S. and Odajima, T.: A direct observation of the peroxidase catalyzed oxidation of halide and thiocyanate ions. Jpn. J. Oral Biol. $30: 334 \sim 339$, 1988.

10) Onishi, M. and Odajima, T.: On the product of prostaglandin $\mathrm{E}_{1}$ oxidized by the myeloperoxidase- $\mathrm{H}_{2} \mathrm{O}_{2}$-chloride system. Jpn. J. Oral Biol. $27: 291 \sim 298,1985$.

11) Onishi, M., Nakamura, S. and Odajima, T. : A chemical discriminating method of myeloperoxidase, lactoperoxidase, saliva peroxidase and horseradish peroxidase. Jpn. J. Oral Biol. $30: 340$ $\sim 346,1988$.

12) Odajima, T., Onishi, M., Hayama, E., Motoji, N., Momose, Y. and Shigematsu, A. : Cytolysis of B16 melanoma tumor cells mediated by the myeloperoxidase and lactoperoxidase systems. Biol. Chem. 377 : 689 693, 1996.

13) Yamazaki, I., Mason, H. S. and Piette, L. : Identification, by electron paramagnetic resonance spectroscopy, of free radicals generated from substrates by peroxidase. J. Biol. Chem. $235: 2444$ $\sim 2449,1960$.

14) In: Atlas of spectral data and physical constants for organic compounds, 2nd edition, vol. II. (Edited by Grasselli, J. G. and Ritchey, W. M.), p. 106, CRC Press, Inc. Cleveland, 1975.

15) Yamazaki, I. and Ohnishi, T. : One-electrontransfer reactions in biochemical systems. I. Kinetic analysis of the oxidation-reduction equilibrium between quinol-quinone and ferro-ferricytochrome $c$. Biochim. Biophys. Acta 112: 469 $\sim 481,1966$.

16) Chance, B.: The properties of the enzyme-substrate compounds of horseradish peroxidase and peroxide. VI. The effect of $\mathrm{pH}$ upon the rate of reaction complex II with several acceptors and its relation to their oxidation-reduction potential. Arch. Biochem. 24: 410 421, 1949.

17) Sapira, J. D. : Chromatography of aromatic amino acid derivatives on polyamide thin layers. J. Chromatog. 42: 134 136, 1969.

18) Pavlov, E. P. and Solov'ev, V. N. : pH changes of cytoplasm in phagocytosis of microorganisms stained with indicator dyes. Byull. Eksp. Biol. Med. 63: 78〜81, 1967.

19) Richter, J., Olofsson, T., Britton, S. and Olsson, I. : Detection of lactoferrin and myeloperoxidase release from single neutrophils by a protein $A$ plaque assay. Scand. J. Immunol. $20: 349 \sim 353$, 1984. 
20) Dang, Y., Lowe, G. M., Edwards, S. W. and Galvani, D.W. : The effects of GM-CSF on myeloperoxidase release in normal and myelodysplastic neutrophils. Leukemia Res. 17:1037 $\sim 1044,1993$.

21) Ozawa, H., Iwao, J., Kowa, Y., Nakagami, S. and Danno, T. : Adrenochrome derivatives. VII.
Hemostatic activities of compounds related to adrenochrome. J. Pharm. Soc. Japan $76: 1367$ $\sim 1370,1956$.

22) Keith, J. H., Keith, W. W. and Nelson, M. H. : Effects of adrenochrome semicarbazone on blood loss in the mouse. J. Pharm. Sci. $56: 997 \sim 1001$, 1967. 